\title{
MAGNETIC SURVEY OF THE DUTCH EAST INDIES.
}

BY DR. W. VAN BEMHLEN.

[First Communication].

It is obvious that the degree of detail of a magnetic survey, as determined by dividing the total area by the number of stations, should be in accordance with the general aims of the survey.

If the observer intends to investigate the relations between geological structure and distribution of the magnetic force, a dense network of stations is required. On the other hand, if he aims at a contribution to the knowledge of the general course of the iso-magnetic curves over the globe, necessary for the derivations of characteristic functions, as for instance the potential function, a much smaller number of stations will suffice.

A detailed survey of the extensive Malay Archipelago crowded with volcanoes, which often are built up by magnetic material, is an undertaking not specially required by the magnetic science of to-day.

A general magnetic survey being within the power of the Batavia Observatory, the Government has granted the necessary means during the years I904-'07. A grant, however, from the "Koninklÿke Natuurkundige Vereeniging in Nederlandsch-Indie" enabled me to commence observations during the year r903. With the aid of the observations of Captain Eliot and of Dr. van Ryckevorsel made respectively, during the years $1845^{-} 49$ and 1874 -' $^{\prime} 7$, the data will be obtained for determining the secular variation of the magnetic elements during the latter half of the past century.

The observations are taken with a new Kew theodolite magnetometer (Elliott No. 94) and a dip circle (Barrow No. 36) with three needles. An apparatus which I have had constructed at Batavia has proved of great value for the observations. A storage battery of two cells (4 volts) and a coil were placed in a box $24 \times$ I6 $X \mathrm{I}_{4} \mathrm{c}$. $\mathrm{m}$. A wooden drawer in which the dip needle is put, is shoved inside the coil from the outside of the box; a closing of the current for a short time suffices to change the polarity of the needle. This quick, easy, and safe manner of reversing the magnetism of the dip needles has improved in a high degreee, the reliability of field observations with the dip circle. A wooden disk, bearing a double coil, wound in opposite directions and two press-contacts, are attached to the battery by long elastic wires. With it, the oscillating magnet may be easily and quickly brought to rest. Finally a small electric lamp (4 volts) also with a press-contact is attached to another elastic wire. Combined with one or two ordinary lamps, it enables the observer to continue his observations at nightfall. When, as in our case, he is obliged to take his observations during the stay of the steamer at some port, it is of the utmost importance that he should be 
independent of day and night time. As the consumption of electric energy is very small, the battery may be in use for ar observing trip lasting a couple of months before requiring replenishing. The box weighs only 6 kilograms and is wholly non-magnetic.

The survey of 1903 has extended over Java and neighboring islands. The values of the magnetic elements, tabulated below, have been reduced according to the Batavia-Buitenzorg-registrations to the epoch 1903-5. The corrections to the field instruments were determined by comparison with the Observatory instruments. This comparison gave the following figures :

\begin{tabular}{lc}
\multicolumn{1}{c}{ Observatory } & Field. \\
Declination, & $-\mathrm{I}^{\prime} \cdot 7 \mathrm{E}$. \\
Inclination, & $+\mathrm{I} \cdot 3 \mathrm{~S}$. \\
Horizontal Intensity, $-40 \mathrm{\gamma}$
\end{tabular}

EPOCE, 1903. 5.

\begin{tabular}{|c|c|c|c|c|c|}
\hline Station. & $\begin{array}{l}\text { Latitude } \\
\text { South }\end{array}$ & $\begin{array}{l}\text { Longitude } \\
\text { E. of Greenw. }\end{array}$ & $\begin{array}{c}\text { Fast } \\
\text { Declination }\end{array}$ & $\begin{array}{c}\text { South } \\
\text { Inclination }\end{array}$ & $\begin{array}{c}\text { For. } \\
\text { Intens. }\end{array}$ \\
\hline $\begin{array}{l}\text { Kata Chyung } \\
\text { Telok Betong } \\
\text { Kalianda } \\
\text { Ondiepwater Island } \\
\text { Tandjong Pandan } \\
\text { Dendang } \\
\text { Buding } \\
\text { Gantung } \\
\text { Manggar } \\
\text { Kebatu } \\
\text { Welteureden } \\
\text { Buitenzorg } \\
\text { Garut } \\
\text { Tjibatu } \\
\text { Boompjes Island } \\
\text { Karimon Djawa } \\
\text { Japara } \\
\text { Pulu Pandjang } \\
\text { Maos }\end{array}$ & $\begin{array}{rrrr} & 0 & \prime & \prime \prime \\
5 & 29 & 0 \\
5 & 27 & 20 \\
5 & 44 & 0 \\
3 & 19 & 10 \\
2 & 44 & 20 \\
3 & 5 & 25 \\
2 & 42 & 0 \\
2 & 58 & 30 \\
2 & 52 & 20 \\
3 & 47 & 30 \\
6 & 11 & 0 \\
6 & 34 & 44 \\
7 & 13 & 1 \\
7 & 5 & 46 \\
5 & 56 & 0 \\
5 & 52 & 50 \\
6 & 35 & 10 \\
6 & 34 & 27 \\
7 & 37 & 0\end{array}$ & 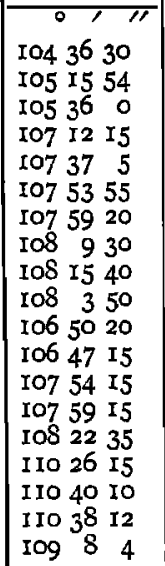 & $\begin{array}{rr}0 & \prime \\
0 & 50.7 \\
0 & 40.2 \\
I & 6.2 \\
I & 22.0 \\
I & 22.1 \\
I & 2.2 \\
I & 23.2 \\
I & 20.9 \\
I & 24.8 \\
I & 18.5 \\
I & 0.0 \\
0 & 37.3 \\
0 & 47.1 \\
I & 2.9 \\
I & 4.6 \\
I & 25.8 \\
I & 9.1 \\
I & 16.6 \\
I & 4.9\end{array}$ & \begin{tabular}{cc} 
& \multicolumn{1}{c}{} \\
29 & 59.0 \\
29 & $4 I .2$ \\
30 & 9.1 \\
24 & 53.7 \\
23 & 35.8 \\
24 & 20.6 \\
23 & 31.0 \\
24 & 1.0 \\
23 & 47.4 \\
25 & 47.3 \\
30 & 23.8 \\
30 & 10.4 \\
32 & 20.6 \\
32 & 11.7 \\
29 & 33.8 \\
29 & 18.9 \\
30 & 39.0 \\
30 & 32.0 \\
32 & 45.4
\end{tabular} & $\begin{array}{r}\gamma \\
36651 \\
673 \\
679 \\
763 \\
771 \\
760 \\
775 \\
767 \\
770 \\
743 \\
670 \\
661 \\
658 \\
646 \\
696 \\
701 \\
687 \\
690 \\
661\end{array}$ \\
\hline Ngupit & 73940 & I IO 3545 & I I. 6 & 32 I 4.1 & $\left.\begin{array}{l}650 \\
675\end{array}\right\}$ \\
\hline $\begin{array}{l}\text { Surabaja-Udjong } \\
\text { Puspo } \\
\text { Tosari } \\
\text { Branta } \\
\text { Banjuwangi } \\
\text { Buleleng } \\
\text { Ampenan } \\
\text { Labuan Hadji }\end{array}$ & $\begin{array}{llll}7 & 12 & 0 \\
7 & 50 & 40 \\
7 & 53 & 50 \\
7 & 12 & 54 \\
8 & 12 & 28 \\
8 & 5 & 40 \\
8 & 34 & 17 \\
8 & 40 & 23\end{array}$ & $\begin{array}{llr}\text { I I } & 44 & \text { II } \\
\text { I I } 2 & 53 & 0 \\
\text { I I } 2 & 55 & 0 \\
\text { I I } 3 & 32 & 20 \\
\text { I I } 4 & 23 & 3 \\
\text { I I } 5 & 5 & 30 \\
\text { I I } 6 & 4 & 9 \\
\text { I I } 6 & 34 & \text { I6 }\end{array}$ & $\begin{array}{rr}\text { I } & 4 \text { I. } 2 \\
\text { I } & 33.3 \\
\text { I } & 44.2 \\
2 & 5 . I \\
\text { I } & 38.9\end{array}$ & $\begin{array}{lr}3 I & 8.2 \\
32 & 3 I .6 \\
33 & 4.4 \\
3 I & 5.8 \\
33 & 0.0 \\
32 & 27.7 \\
32 & 23.7 \\
33 & 56.6\end{array}$ & $\begin{array}{l}695 \\
-- \\
707 \\
660 \\
686 \\
682 \\
652\end{array}$ \\
\hline
\end{tabular}

